\title{
THE SIZE OF THE COMPANY IS MODERATING EARNING AGGRESIVENESS AND RETURN ON ASSET ON THE LEVERAGE
}

\author{
Melinda Malau \\ Program Studi Akuntansi Universitas Kristen Indonesia \\ Email: melindamalau_1982@yahoo.com
}

\begin{abstract}
This study aims to examine and analyze whether earning aggresivenessaffects the leverage, return on asset affects the leverage, the size of the company can moderate the effect ofearning aggresivenesson the leverage, the size of the company can moderatereturn on asset on the leverage. The sample used in this study is 500 observational data using data from manufacturing companies for the period 20142018. The first model is without moderation variable, while the second model iswith moderating variable. The results of the first model and second model show that earning aggressiveness has a significant positive effect on the leverage. Return on asset has a significant negative effect on the leverage. Size strengthens the effect of earnings aggressiveness on the leverage.Size strengthens the effect of return on asset on the leverage.In making investment decisions, investors must evaluate the quality of earnings reporting.
\end{abstract}

Keywords: leverage; earning aggresiveness; return on asset; size.

\begin{abstract}
Abstrak
Penelitian ini bertujuan untuk menguji dan menganalisis apakah keagresifan laba mempengaruhi tingkat rasio utang, tingkat pengembalian aset mempengaruhi tingkat rasio utang, ukuran perusahaan dapat memoderasi pengaruh keagresifan laba pada tingkat rasio utang dan ukuran perusahaan dapat memoderasi tingkat pengembalian aset pada tingkat rasio utang. Sampel yang digunakan dalam penelitian ini adalah 500 data amatan yang menggunakan data dari perusahaan manufaktur untuk periode tahun 2014-2018. Model pertama adalah tanpa menggunakan variabel moderasi, sedangkan model kedua adalah dengan menggunakan variabel moderasi. Hasil penelitian dari model pertama dan model kedua menunjukkan bahwa keagresifan laba memiliki pengaruh signifikan positif terhadap tingkat rasio utang. Tingkat pengembalian aset memiliki pengaruh signifikan negatif terhadap tingkat rasio utang. Ukuran perusahaan memperkuat pengaruhkeagresifan laba terhadap tingkat rasio utang. Ukuran perusahaan memperkuat pengaruh tingkat pengembalian aset terhadaptingkat
\end{abstract}

* Corresponding author's e-mail: melindamalau_1982@yahoo.com http://openjournal.unpam.ac.id/index.php/JABI 
rasio utang. Dalam membuat keputusan investasi, investor harus mengevaluasi kualitas pelaporan laba.

Kata kunci: tingkat rasio utang, keagresifan laba, tingkat pengembalian aset, ukuran perusahaan.

\section{INTRODUCTION}

Earning aggressiveness is a management level action related to earnings manipulation (Bedard \& Johnstone, 2004). Earning aggressiveness as a behavior that leads to the tendency to postpone the recognition of losses but accelerate the recognition for corporate profits. Earning aggressiveness also affects the decline in earning quality (Altamuro et al., 2005). The rate of return on assets is one form of profitability ratios. The rate of return on assets to measure a company's ability to generate profits using the total assets available and after cost of capital (cost used to fund assets) are excluded from financial analysis (Ahmed et al., 2002). Some literature suggestt the agrresive earning is measured form level or total accrual obtained from change in total current assets minus total current liabilities changes. Changes in cash, depreciation plus the change in long term debt and current maturities of debt tax changes. All these components are divided by total assets a year ealier.

An increase in the value of an asset is a signal to the size of the company. If the size of the company increases, it is expected that company profits and dividends will also increase. The size of the company is based on total assets with the argument that management through accrual policy can increase the value of company assets. Information processing cost considerations reflect the relationship between company size and company financial statements. Information that is processed by large companies is generally more complex compared to smaller companies. Large companies are better able to finance the information needed. Research conducted proves that large companies will present the company's financial statements compared to small companies to be able to minimize the possibility of the pressures they experience (Cooke, 1992; Alsaeed, 2006). The level of debt ratio illustrates the extent to which owner's capital can cover debt to outsiders and is a ratio that measures the extent to which companies are financed from debt. This ratio is also called the leverage ratio (Gunawan, 2000).

This study examines manufacturing companies with a research period of four years (2014-2018). Manufacturing companies listed on the stock exchange were selected as research samples in the country of Indonesia. Indonesia is used as a research sample because it is the domicile of researchers. Indonesia is also dynamic as a means of business funding and an additional means of investor capital.

* Corresponding author's e-mail: melindamalau_1982@yahoo.com

http://openjournal.unpam.ac.id/index.php/JABI 
The purpose of this study is to test and analyze (1) whether earning aggressiveness affects the leverage; (2) whether the return on asset affects the leverage; (3) whether the size of the company can moderate the effect of earning aggressiveness on the leverage; (4) whether the size of the company can moderate the effect of return on asseton the leverage.

Research contributions include theoretical contributions and practical contributions. This study confirms whether the leverage can be explained by a variety of factors examined. The theoretical contribution of this research is significant for science, including (i) the effect of the earning aggressiveness and return on asseton leverage, and (ii) measurement of company size that moderates (strengthens or weakens) the effect of earning aggressiveness and return of asseton the leverage. The practical contribution of the results of this study is to consider the size of the company to control the level of debt ratio in the annual report and to pay more attention to the calculation of its composition (in the annual report produced so that the company is able to make optimal investment decisions).

The significance of this study is to analyze whether a company has considered company size as a moderating variable in this study. This study examines the effect of the company's earning aggressiveness and the return of asset of manufacturing company on the leverage. In this study using the variable size of the company because the researcher wants to investigate whether the consideration of the size of the company underlying the presentation of financial statements can strengthen or weaken the effect of the earning aggressiveness and return on asset on the leverage.

\section{THEORETICAL FRAMEWORK AND DEVELOPMENT OF HYPOTHESES}

\section{Earning Aggresiveness on Leverage}

Sunarto et al. (2016) states that the earning aggressiveness affects investors in making decisions in the company. Mendes-Da-Silva et al. (2014) uses the leastsquares regression equation in his research. The result is that, on average, more aggressive companies show higher cost of capital and are supported by a lack of research on various ways to estimate cost of capital and their relationship to disclosure through company websites. Sunarto (2010) and Bhattacharya et al. (2003) states that earning aggressiveness will lead to earning blur. The leverage illustrates the extent to which owner's capital can cover debt to outsiders and is a ratio that measures the extent to which companies are financed from debt (Suripto, 1999; Subiyantoro, 1997; Gunawan, 2000). Leverage is a ratio to measure how good the company's capital structure. The capital structure is permanent funding consisting of long-term debt, preferred shares and shareholder capital (Wahyono, 2002). Based on this discussion, the researcher proposes the following hypothesis:

\section{$H_{1}$ : Earning aggressiveness has a positive effect on the leverage.}




\section{Return On Asset on Leverage}

Return on asset is the ratio of net income to total company assets (Nikoomaram et al., 2011; Francis et al., 2008; Ahmed et al., 2002). The higher return on asset, the better the value of the company. The level of debt ratio is the ratio between long-term debt with total assets of the company (Murwaningsari, 2013). The higher the level of debt ratio means the lower the value of the company. Based on this discussion, the researcher proposes the following hypothesis:

\section{$H_{2}$ : Return on asset has a negative effect on the leverage.}

\section{Firm SizeStrengthens the Effect of EarningAggressiveness on the Leverage.}

Chadha \& Sharma(2015) found that firm size had a significant effect on determinants of capital structure in Indian manufacturing sector companies. This study uses a sample of 422 companies listed on the Bombay Stock Exchange in conducting empirical evaluations. Alipouret al.(2015) concluded that firm size has a significant effect on the capital structure of manufacturing companies in Iran. Study sample of companies listed on the Tehran Stock Exchange. This study examines differences in the conditional theory of capital structure to formulate testable propositions relating to the determination of the capital structure of companies in Iran.Based on these explanations, the researchers propose the following research hypotheses:

\section{H3: Firm size strengthensthe effect of earning aggressiveness on the leverage.}

\section{Firm SizeStrengthens the Effect of Return on Asset on the Leverage.}

The results of a study in Borja(2015) concluded that the larger the company, the lower the cost of equity capital. Large companies have more liquidity and have more bargaining power over suppliers of capital. Information processing cost considerations reflect the relationship between company size and company financial statements. Information that is processed by large companies is generally more complex compared to smaller companies. Large companies are better able to finance the information needed. Research conducted proves that large companies will present financial statements of companies compared to small companies to be able to minimize the possibility of the pressures they experience (Singhvi and Desai, 1971; Cooke, 1992; Alsaeed, 2006).Based on these explanations, the researchers propose the following research hypotheses:

H4: Firm size strengthens the effect of return on asset on the leverage.

\section{RESEARCH METHOD}

\section{Research Design}


Based on the problems in this study, the type of research used is hypothesis testing whether there is an effect of earning aggressiveness and return on asseton the leverage with company size as a moderating variable in manufacturing companies in Indonesia. Testing the hypothesis is causal. The time period used in this study was five years from the 2014-2018 period. The setting environment is the real environment. The unit of analysis used in this study uses data on financial statements of manufacturing companies in Indonesia that have been audited and listed on the stock exchange, has a corporate website and other supporting websites.

\section{Variables and Measurements Dependent Variable}

The debt ratio measurement test in this study is long-term debt divided by total company assets (Murwaningsari, 2013; Suripto, 1999; Subiyantoro, 1997; Gunawan, 2000). This ratio is also called the leverage ratio. Leverage ratio is a ratio to measure the company's capital structure.

\section{Independent Variable}

Some independent variables that will be tested to determine the relationship with the dependent variable in this study are as follows:

\section{Earning Aggressiveness}

The calculation for earning aggressiveness (Bhattacharya et al., 2003) is measured in the following stages.

\section{Stage 1:}

$$
Y=\alpha+\beta_{1} \frac{\Delta C A_{k t}}{T A_{k t-1}}+\beta_{2} \frac{\Delta C L_{k t}}{T A_{k t-1}}+\beta_{3} \frac{\Delta \operatorname{Cash}_{k t}}{T A_{k t-1}}+\beta_{4} \frac{\Delta S T D_{k t}}{T A_{k t-1}}+\beta_{5} \frac{\Delta D E P_{k t}}{T A_{k t-1}}+\beta_{6} \frac{\Delta T P_{k t}}{T A_{k t-1}}+\varepsilon
$$

Explanation:

$\mathrm{Y}=$ Scale of accrual company $\mathrm{k}$ year $\mathrm{t}($ EBITDA / TA $\mathrm{kt}-1)$

$\triangle C A_{\mathrm{kt}}=$ Change in total current assets for the company $\mathrm{k}\left(C A_{\mathrm{kt}}-C A_{\mathrm{kt}-1}\right)$

$\triangle C L_{\mathrm{kt}}=$ Changes in the total current debt company $\mathrm{k}\left(C L_{\mathrm{kt}}-C L_{\mathrm{kt}-1}\right)$

$\triangle C A S H_{\mathrm{kt}}=$ Changes in cash for company k $\left(\right.$ Cash $_{\mathrm{kt}}-$ Cash $\left._{\mathrm{kt}-1}\right)$

$\triangle S T D_{\mathrm{kt}}=$ Changes in Short Term Debt $\left(S T D_{\mathrm{kt}}-S T D_{\mathrm{kt}-1}\right)$ company k

$D E P_{\mathrm{kt}}=$ Depreciation and amortization expense company kyear $\mathrm{t}$

$\Delta T P_{\mathrm{kt}}=$ Changes intax payable $\left(T P_{\mathrm{kt}}-T P_{\mathrm{kt}-1}\right)$

EBITDA = Earning Before Interest, Tax, Depreciation, and Amortization

$T A_{\mathrm{kt}-1}=$ Total asset company $\mathrm{k}$, year $\mathrm{t}-1$

\section{Return on Asset}

Return on asset is measured by net income divided by total assets in company (Nikoomaram et al., 2011; Francis et al., 2008; Ahmed et al., 2002).

\section{Moderation Variable: Company Size}


The size of the company is estimated by using the natural logarithm of total assets (Singhvi dan Desai, 1971; Cooke, 1992; Alsaeed, 2006; Francis et al., 2004).

\section{Data Analysis Method Empirical Research Model}

In this study, the test was done without moderation variable first, then the test was done with moderation variable. Testing is done to see whether the size of the company can strengthen the effect of the earning aggressiveness and the return on asseton leverage in manufacturing companies listed in Indonesia.

The following is a breakdown of the research equation model based on research hypotheses. The first model is to test the effect between the earningaggressiveness and return on asseton leverage (equation 2). The second model is to examine the effect between the earningaggressiveness and return on asseton leverage with the size of the company as a moderating variable (equation 3 ).

$$
\begin{aligned}
& L E V_{\text {it }}=\beta_{0}+\beta_{1} A G G R E S S_{\text {it }}+\beta_{2} R O A_{\text {it }}+\varepsilon_{\text {it }} \quad \ldots(2) \\
& L E V_{\text {it }}=\beta_{0}+\beta_{1} A G G R E S S_{\text {it }}+\beta_{2} R O A_{\text {it }}+\beta_{3} S I Z E_{\text {it }}+\beta_{4}\left(A G G R E S{ }^{*} S I Z E\right)_{\text {it }}+\beta_{5}(R O A * S I Z E)_{\text {it }}+\varepsilon_{\text {it }}
\end{aligned}
$$

Explanation:

$L E V=$ leverage

$A G G R E S S=$ Earningaggressiveness

$R O A=$ Return On Asset

$S I Z E=\log$ total asset in company

$\varepsilon=$ Error

\section{RESULT AND CONCLUSIONS}

\section{Descriptive Statistics and Correlation Matrix}

In this study conducted a descriptive statistical analysis with the aim to determine the distribution of data in the form of central tendencies and data dispersion. The results of the descriptive statistical analysis of the research variables are presented in Table 1.

Table 1.Descriptive Statistics- Research Variable

\begin{tabular}{|lr|r|r|r|r|}
\hline & $\mathrm{N}$ & Minimum & Maximum & \multicolumn{1}{c|}{ Mean } & Std. Deviation \\
\hline $\begin{array}{l}\text { Dependent Variable: } \\
\text { LEV }\end{array}$ & 500 & 0.02315 & 0.05330 & 0.03322 & 0.01333 \\
$\begin{array}{l}\text { Independent Variable: } \\
\text { AGGRESS }\end{array}$ & 500 & -0.21155 & 0.73660 & 0.26261 & 0.32433 \\
ROA & 500 & -0.04313 & 0.03220 & 0.01321 & 0.08131 \\
$\begin{array}{l}\text { Moderation Variable: } \\
\text { SIZE }\end{array}$ & 500 & -0.76321 & 8.02136 & 3.79222 & 0.75330 \\
Note: This table represents descriptive statistics of each research variable. The purpose of this table is \\
\hline
\end{tabular}

* Corresponding author's e-mail: melindamalau_1982@yahoo.com http://openjournal.unpam.ac.id/index.php/JABI 
to provide a description of the central tendency conditions and data dispersion used in estimating the research model. The dependent variable is $L E V$. The independent variables are AGGRESS, ROA, and the interaction between AGGRESS, ROA and SIZE. The moderation variable is SIZE.

Source: Data processed

Based on the data in Table 1 that the debt ratio variable ( $L E V)$ has the lowest value of 0.02315 and the highest value of 0.05330 . The debt ratio $(L E V)$ variable has a smaller standard deviation compared to the average value. This shows that the debt ratio $(L E V)$ variable of the sample companies has a fairly low variation of these variables. Earnings aggressiveness (AGGRESS) has a relatively small mean value compared to the standard deviation value. This shows that the aggressiveness variability of the sample company's earnings is quite high. Most of the sample companies do aggressively uneven and fluctuating earnings. The rate of return on assets $(R O A)$ has a relatively small mean value compared to the standard deviation value. The variable return on assets $(R O A)$ has a positive average and there is a high enough variation of these variables for the sample company.

\section{Hypothesis Test Results}

The classic assumption test of this research model shows that the model does not experience multicollinearity, heteroscedasticity and autocorrelation problems.

\section{The Results of Testing the First Model Research Hypothesis}

The first model test is a regression test conducted to see the effect of earnings aggressiveness and the rate of return on assets on the leverage. The results of testing the first model research hypothesis are presented in Table 2.

Table 2.The Results of Testing the First Model

\begin{tabular}{|c|c|c|c|c|c|}
\hline \multicolumn{5}{|c|}{$\beta_{0}+\beta_{1} A G G R E S S_{\mathrm{it}}+\beta_{2} R O A{ }_{\mathrm{it}}+\varepsilon_{\mathrm{it}}$} & \\
\hline \multirow[t]{2}{*}{ Variable } & \multirow[t]{2}{*}{ Prediction } & \multirow[t]{2}{*}{ Coefficient } & \multirow[t]{2}{*}{ P-Value } & \multicolumn{2}{|c|}{ Statistic Collinearity } \\
\hline & & & & Tolerance & VIF \\
\hline Constanta & & 0.1412 & 0.0000 & -- & -- \\
\hline AGGRESS & + & 0.1722 & $0.0000 * * *)$ & 0.8055 & 1.2415 \\
\hline \multirow[t]{7}{*}{$R O A$} & - & -0.0645 & $\left.0.0255^{* *}\right)$ & 0.7341 & 1.3623 \\
\hline & Normality Test & 0.9903 & & & \\
\hline & in-Watson Stat & 1.7990 & & & \\
\hline & Glejser Test & 0.2651 & & & \\
\hline & Adjusted $\mathrm{R}^{2}$ & 0.6213 & & & \\
\hline & ob (F-Statistik) & $0.0000 * * *)$ & & & \\
\hline & tal Observation & 500 & & & \\
\hline $\begin{array}{l}* * * \text { Significal } \\
\text { Note: This tal } \\
\text { to provide a c } \\
\text { research mode }\end{array}$ & $\begin{array}{l}\text { the level } 1 \% \text {; } \\
\text { epresents descr } \\
\text { ription of the } \\
\text { he dependent }\end{array}$ & $\begin{array}{l}\text { gnificantat the } \\
\text { ve statistics of } \\
\text { ral tendency co }\end{array}$ & $\begin{array}{l}\text { 15\%; * Signif } \\
\text { h research var } \\
\text { ions and data }\end{array}$ & $\begin{array}{l}\text { antat thelevel } \\
\text { le. The purp } \\
\text { spersion usec }\end{array}$ & his table is \\
\hline
\end{tabular}

Source: Data processed, regression output 


\section{The Results ofTesting the Second Model Research Hypothesis}

This second model test is a regression test conducted to see the effect of the earning aggressiveness and return on asset on the leverage with company size as a moderating variable. A summary of the results of testing the second model can be seen in Table 3.

Table 3. The Results of Testing the First Model

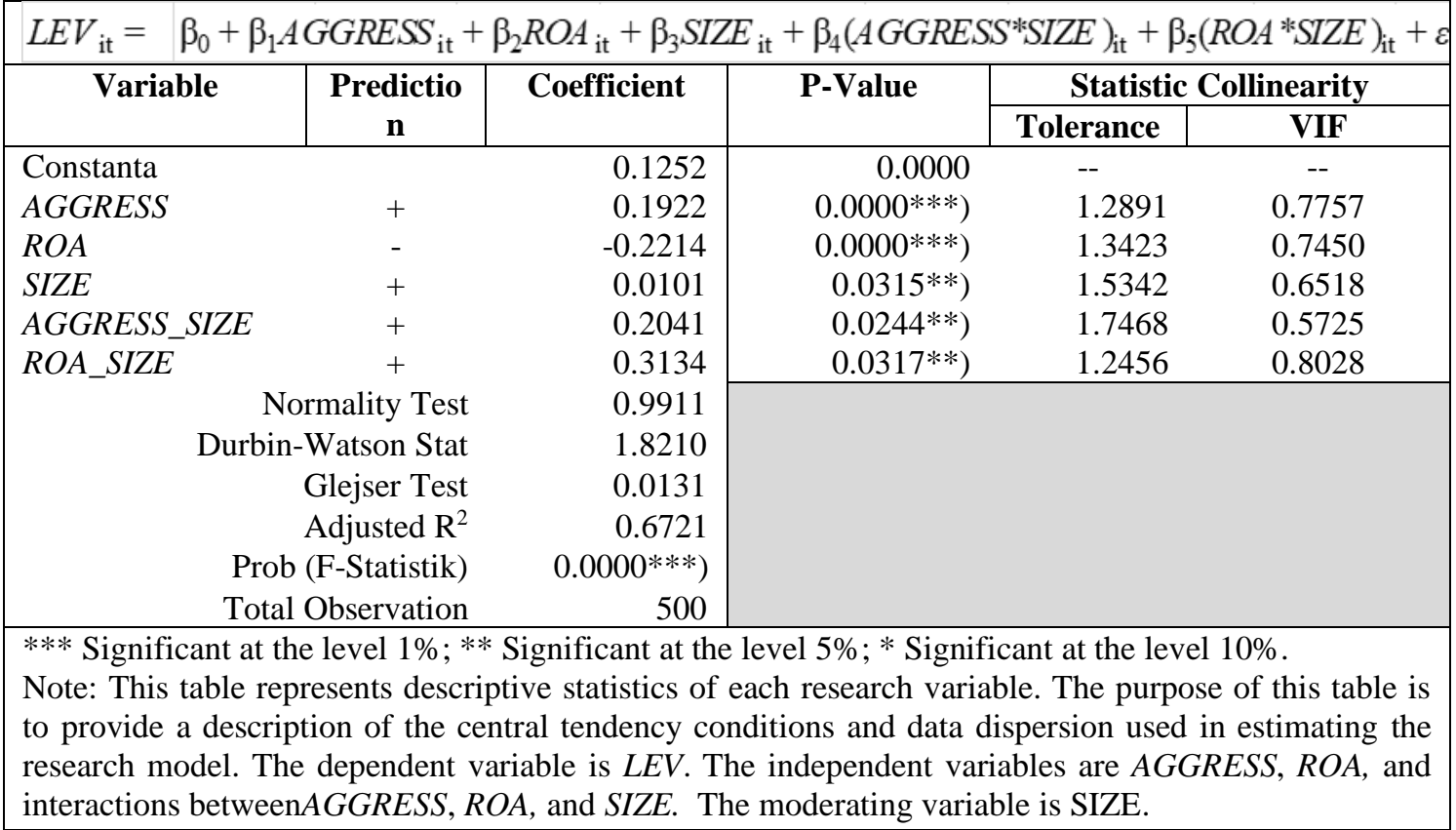

Source: Data processed, regression output

This study aims to examine the effect of the earninga ggressiveness and return on asset on the leverage by using company size as a moderating factor. Earning aggressiveness has a significant positive effect on the leverage. This indicates that the earning aggressiveness can increase the level of debt ratios that affect the decline in company performance and increase company risk. High risk will increase company costs. The rate of return on assets has a significant negative effect on the leverage. This indicates that the rate of return on assets increases the risk of the company. High risk will increase company costs. The higher the long-term debt, the lower the value of the company.

\section{IMPLICATIONS AND LIMITATIONS}

Based on the results of tests that have been done, the results of this study can have managerial implications. The quality of a company's earnings reporting will be high or low is not only determined by accounting policies or company internal 
factors. The role of the regulator is very necessary for the supervision of earnings reporting. A concrete example is the formulation of regulations in a country's Financial Accounting Standards which is implemented as a form of limiting the flexibility of accounting policies and to narrow the opportunist attitudes of company management.

Research has limitations that need to be addressed so that the interpretation of research results is carried out carefully by considering existing limitations. In addition, the limitations of existing research are useful to be considered for future research. The limitations referred to are (1) The results of this study cannot be generalized to all countries. The results of the study only apply to publicly traded companies in the country of Indonesia; (2) In the research sample of companies that go public, there are components such as depreciation and amortization costs that are not separated from the company cost component, so researchers must check back to the notes on financial statements and annual reports.

Suggestions for further research are as follows (1) Extending the sample of companies by industry category. In this study using manufacturing companies only. Future studies can use company samples for all categories of industries, except the financial industry because of their different characteristics; (2) Adding more research samples from ASEAN countries. This research is limited to Indonesia.

\section{REFERENCES}

Ahmed, A., Billings, B., Morton, R., \& Harris, M. (2002). The Role of Accounting Conservatism in Mitigating Bondholder-Shareholder Conflicts Over Dividend Policy and in Reducing Debt Costs. The Accounting Review, 77, 867-890.

Alipour, M., Mohammadi, M. F. S., \& Derakhshan, H. (2015). Determinants of Capital Structure: An Empirical Study of Firms in Iran. International Journal of Law and Management, 57(1), 53-83. https://doi.org/10.1108/IJLMA-01-20130004

Alsaeed, K. (2006). The Association Between Firm-Spesific Characteristics and Disclosure: The Case of Saudi Arabia. Managerial Auditing Journal, 21(5), 476-496.

Altamuro, J., Beatty, A., \& Weber, J. (2005). The Effects of Accelerated Revenue Recognition on Earnings Management and Earnings Informativeness: Evidence from SEC Staff Accounting Bulletin 101. The Accounting Review, 80(2), 373401.

Bedard, J., \& Johnstone, K. (2004). Earnings Manipulation Risk, Corporate Governance Risk, and Auditors' Planning and Pricing Decisions. The Accounting Review, 79(2), 277-304.

Bhattacharya, U., Daouk, H., \& Welker, M. (2003). The World Price of Earnings 
$\begin{array}{llll}\text { Opacity. Accounting } & \text { Review }\end{array}$ https://doi.org/10.2308/accr.2003.78.3.641

Borja, D. V. H. (2015). Effect of Auditor Choice and Tenure on the Cost of Equity Capital of Selected Listed Firms in the Philippines. Philippine Management Review, 22, 1-20. Retrieved from http://ovcrd.upd.edu.ph/pmr/article/view/4519

Chadha, S., \& Sharma, A. K. (2015). Determinants of Capital Structure: An Empirical Evaluation From India. Journal of Advances in Management Research, 12(1), 3-14. https://doi.org/10.1108/JAMR-08-2014-0051

Cooke, T. (1992). The Impact of Size, Stock Market Listing and Industry Type On Disclosure In The Annual Reports of Japanese Listed Corporations. Accounting and Business Research, 22(87).

Francis, J., LaFond, R., Olsson, P., \& Schipper, K. (2004). Costs of Equity and Earnings Attributes. The Accounting Review, 79(4), 967-1010. https://doi.org/10.2139/ssrn.414125

Francis, J., Nanda, D., \& Olsson, P. (2008). Voluntary Disclosure, Earnings Quality, and Cost of Capital. Journal of Accounting Research, 46(1), 53-99. https://doi.org/10.1111/j.1475-679X.2008.00267.x

Nikoomaram, H., Hamidreza, V. F., Fraydoon, R. R., Ghodratollah, T., \& Peyman., A. (2011). Conceptual Model for Relationship Between Earning Quality and Cost of Capital. African Journal of Business Management, 5(22), 9724-9733.

Singhvi, S., \& Desai, H. (1971). An Empirical Analysis of the Quality of Corporate Financial Disclosure. The Accounting Review, 129-138. 